\title{
Impact potential of hypersaline brines released into the marine environment for CCS reservoir pressure management
}

\author{
Marius Dewar ${ }^{\mathrm{a}, *}$, Jerry Blackford ${ }^{\mathrm{a}}$, Tony Espie ${ }^{\mathrm{b}}$, Sarah Wilford ${ }^{\mathrm{c}}$, Nicolas Bouffin ${ }^{\mathrm{c}}$ \\ ${ }^{a}$ Plymouth Marine Laboratory, Prospect Pl., Plymouth PL1 3DH, United Kingdom \\ ${ }^{\mathrm{b}}$ BP International Limited, Chertsey Road, Sunbury on Thames, Middlesex TW16 7BP, United Kingdom \\ ${ }^{\mathrm{c}}$ BP Exploration Operating Company Ltd, Chertsey Rd, Sunbury-on-Thames, Middlesex, TW16 7LN, United Kingdom
}

\section{A R T I C L E I N F O}

\section{Keywords:}

Storage

Saline aquifers

Pressure management

Environmental Impact

\begin{abstract}
A B S T R A C T
The environmental impact potential arising from the possible disposal of hypersaline brines into the ocean as part of reservoir pressure management for Carbon Capture and Storage is assessed using sophisticated high-resolution hydrodynamic models for the first time, investigating several industry guided scenarios. Although the characteristics of some brines in their undiluted form would have a high environmental impact potential, we find that dispersion in a hydrodynamically active region like the North Sea acts to dilute disposed brine rapidly, even in a worst case approach, such that the potential impact footprint (area exposed to environmentally damaging salinity or temperature) is small, measured in $10^{\prime}$ s of meters depending on the release scenario and site specific data such as the hypersaline water contaminants along with in-situ conditions such as currents and mixing. The method of brine disposal has a significant influence on dispersal, such that brines released nearer the sea surface disperse more rapidly, compared with release at the seabed. Hence consideration of brine release height is recommended to further limit impact potential.
\end{abstract}

\section{Introduction}

Carbon Capture and Storage (CCS) is a necessary technique to mitigate the threat to the global climate from fossil fuel and other industrial sources of anthropogenic carbon dioxide $\left(\mathrm{CO}_{2}\right)$ emissions (Pachauri et al., 2014), along with the need to continue relying on fossil fuels to meet the continued primary energy consumption by human populations for the short to medium term (Raupach et al., 2007). Emissions have rapidly increased since the industrial revolution and although they are beginning to level off, they have yet to start reducing (Friedlingstein et al., 2020). In the International Energy Agency's scenarios, CCS is required to provide at least a $14 \%$ reduction in $\mathrm{CO}_{2}$ emissions by 2060 compared to 2014 levels (IEA, 2017), contributing to an $80-95 \%$ reduction in anthropogenic $\mathrm{CO}_{2}$ emissions by 2050 (Metz and Intergovernmental Panel on Climate Change, 2005; Pachauri et al., 2014). CCS involves capturing $\mathrm{CO}_{2}$ from point source emitters, compressing, and burying the compressed $\mathrm{CO}_{2}$ in geological formations. Utilising depleted oil and gas reservoirs or saline aquifers (Metz and Intergovernmental Panel on Climate Change, 2005) deep below the seabed has been actively pursued since 1996, albeit in a small scale, driven in part by carbon taxes (Edenhofer and Intergovernmental Panel on Climate
Change, 2014; Sumner et al., 2009). However, to have any meaningful impact on climate change mitigation, investment in CCS needs to be scaled up by orders of magnitude (Zapantis et al., 2019).

Pressure management of reservoirs used for carbon dioxide storage may be a key component of maintaining caprock and reservoir integrity of the storage complex (Buscheck et al., 2016) and thereby storage capacity. Where storage utilizes saline aquifers, pressure management may potentially require production of reservoir brines and their dispersion in over-lying seawater or re-injection to a secondary storage facility as shown in Fig. 1. Whilst the characteristics of these brines vary greatly, some may be hypersaline (exceeding $200 \mathrm{PSU}$ ), hot (exceeding $50{ }^{\circ} \mathrm{C}$ ), anoxic and / or with elevated levels of contaminants such as heavy metals (Fouillac et al., 2009). In their undiluted form, such brines have the potential to be detrimental to ecosystems. However, dispersion and dilution in well mixed shelf sea environments act to reduce this impact potential.

In marine systems away from estuaries salinity varies between approximately 33 PSU (in polar regions with ice melt) (Barry and Hall-McKim, 2018) to 39 PSU (enclosed basins such as the Mediterranean) (Techtmann et al., 2015). Species tend to be adapted to either brackish or oceanic conditions with only highly specialized communities

\footnotetext{
* Corresponding author.

E-mail address: made@pml.ac.uk (M. Dewar).
} 
able to tolerate metahaline ( $>45$ PSU) systems (Remaili et al., 2018). Marine temperature varies between $-2.0^{\circ} \mathrm{C}$ (Polar) to $30^{\circ} \mathrm{C}$ (tropical) (Sumich and Morrissey, 2004), although site specific ranges tend to be less than $10{ }^{\circ} \mathrm{C}$ at the seabed and most species are adapted to regional temperature ranges. Above $35^{\circ} \mathrm{C}$ enzyme function becomes sub-optimal and rapidly declines as temperature increases (Corporation, 1972). There is a growing trend of de-oxygenation globally, driven by eutrophic conditions or changes in mixing imposed by climate warming (Wakelin et al., 2020). In general, shelf seas have oxygen levels in excess of $7 \mathrm{mg} / \mathrm{l}$, but sporadic anoxia is frequently recorded $(<4.7 \mathrm{mg} / \mathrm{l})$ (Topcu and Brockmann, 2015). Assessing impact potential on a given ecosystem, species or individual is however complex. Stress responses and thresholds are species and life-stage specific, depend on exposure time and can be greatly exacerbated if multiple stressors are present. Many species are able to tolerate infrequent short-lived exposures to restricted numbers of stressors (Smyth and Elliott, 2016), especially if well nourished, however constant exposure to fluctuating stressors can be particularly compromising.

With the intention of assessing the impacts of large-scale disposal of produced reservoir brines into the marine environment using a nested suite of hydrodynamic models, our key question is: Is the natural mixing in marine systems along with induced mixing from the high-density release sufficient to disperse and dilute these brines below ecological impact thresholds? We consider different brine release rates and modes, focusing on the upper estimates of release rates within a tidally influenced marine settings typical of the North Sea but analogous to global shelf sea systems.

Hypersaline hydrodynamic studies have been conducted in high salinity lakes (Abbaspour et al., 2012; Ali Bek AbdelRhman and Cowles, 2018; Chamanmotlagh and Safaie, 2021; Dabestani et al., 2020; Ibrahim et al., 2020) and in respect to releases from desalination plants (Hodges, 2010; Ibrahim et al., 2020; Palomar and Losada, 2011). Here, similar modelling approaches are used to develop a first order understanding of plume behaviour as a precursor to recommending an observational strategy to deliver a site-specific evaluation. The hydrodynamic model FVCOM used in this study has been validated for hypersaline mixing in a number of studies (Abbaspour et al., 2012; Ali Bek AbdelRhman and Cowles, 2018; Chamanmotlagh and Safaie, 2021; Dabestani et al., 2020; Ibrahim et al., 2020), giving reassurances to the efficacy of the model outputs.

\section{Methodology}

\subsection{Model set-up}

In this study we use a very high-resolution hydrodynamic model system, utilising the Unstructured Grid, Finite-Volume Coastal Ocean Model (FVCOM) (Chen et al., 2007), to assess the dispersion of hypersaline brines in the natural environment. FVCOM is an unstructured-grid, coastal hydrodynamic circulation model, with the atmospheric weather forcing through the free surface. The primitive 3D equations of continuity, momentum, energy and tracers are solved to simulate the multiscale dynamics of the hydrodynamic turbulent flows. This model system allows for very high resolution in the vicinity of the release point, such that the dynamics and dispersion of plumes can be modelled in detail. Lower resolution towards the model domain boundaries restricts computational cost but maintains the ability of the model system to accurately simulate the primary physical mixing process acting on shelf seas. The model system has been adapted to enable the simulation of sea surface, mid-depth, and seabed hypersaline brine releases, at multiple points. Detailed bathymetry as shown in Fig. 2, enables the assessment of any impact seabed morphology may have on dispersal or retention of brines. We have chosen the domain as one where CCS storage in saline aquifers has been identified as plausible (Pale Blu Dot 2016).
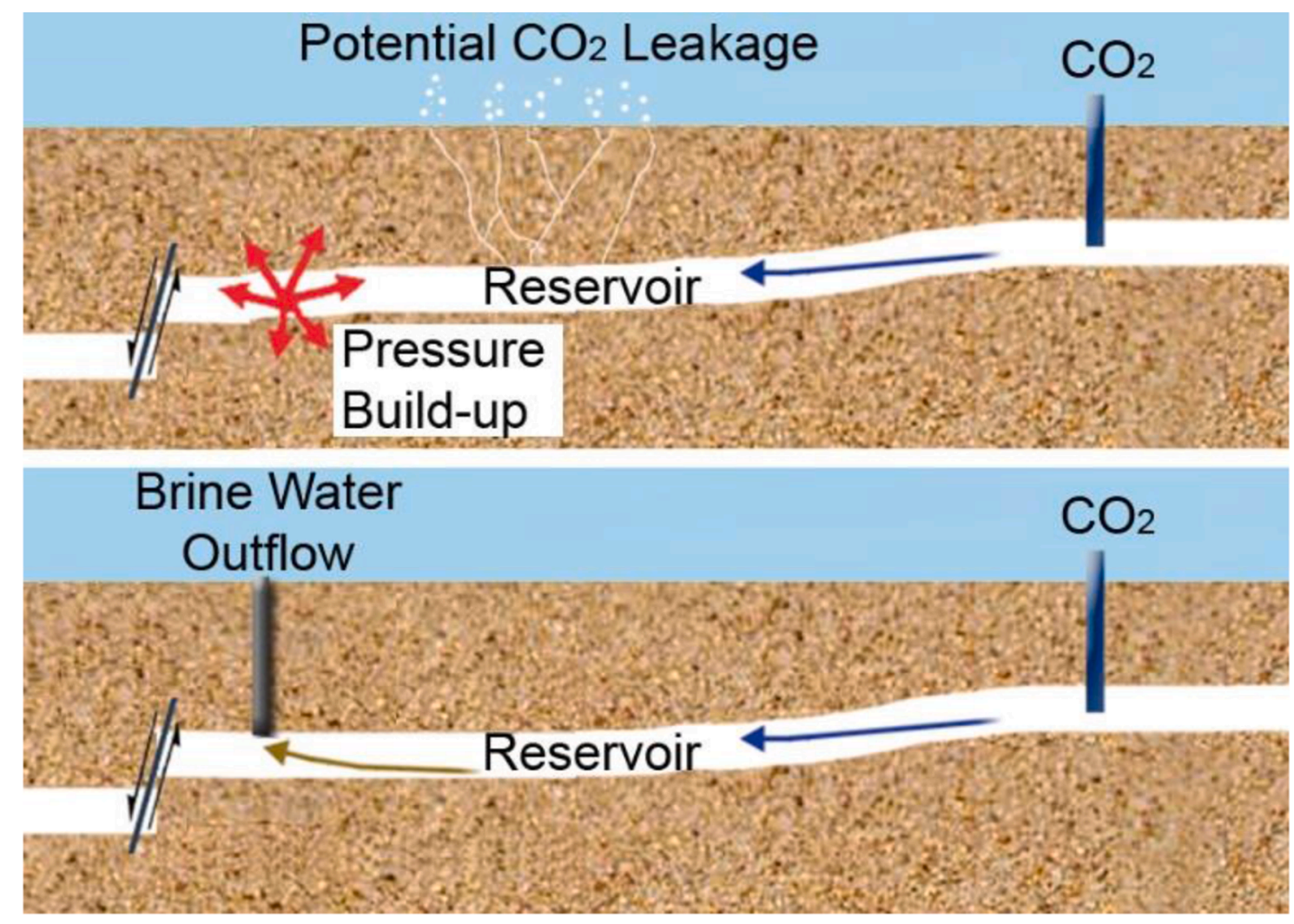

Fig. 1. Schematic of the threat from reservoir pressure build-up, with the potential of faults fractures and $\mathrm{CO}_{2}$ leakage (top); and a suggested solution to manage reservoir pressures (bottom). 


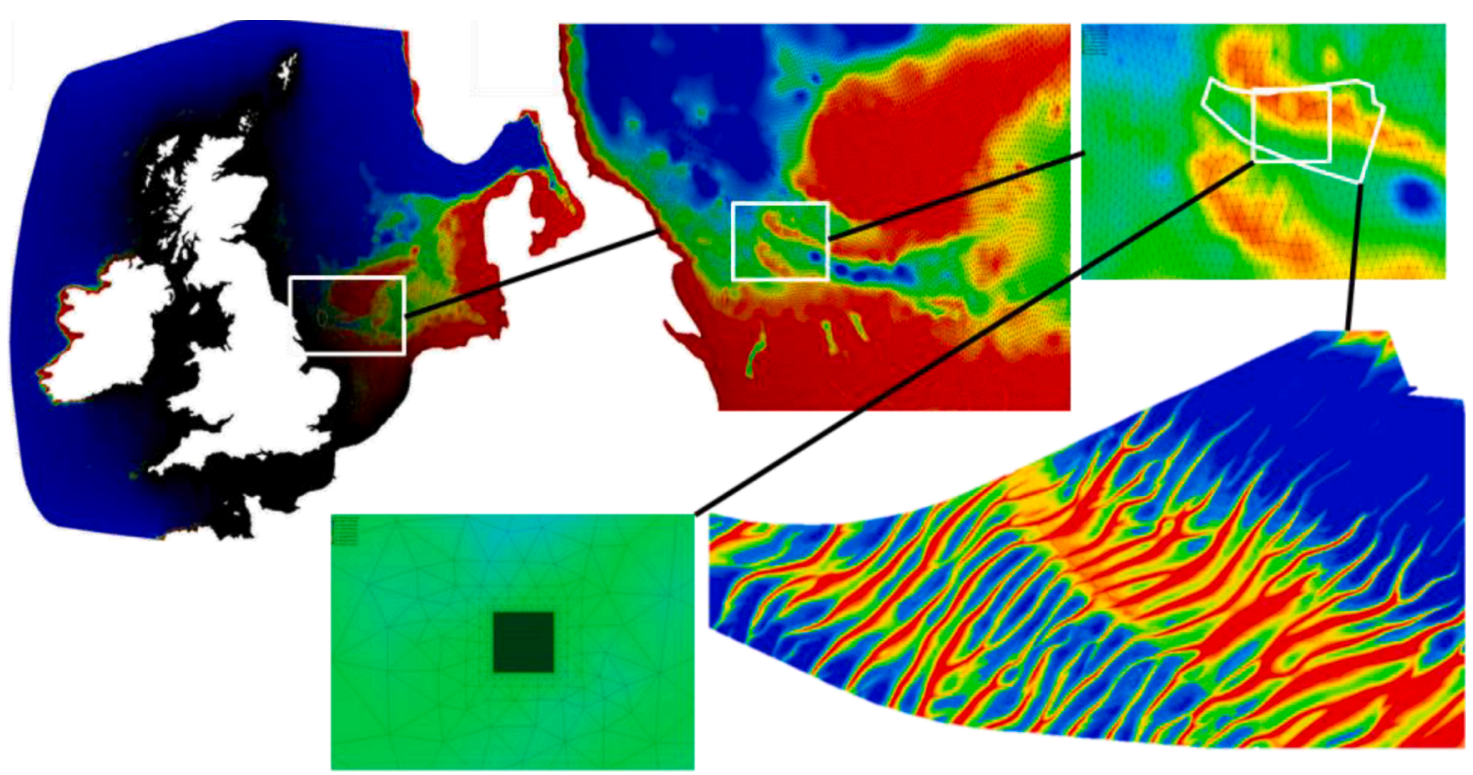

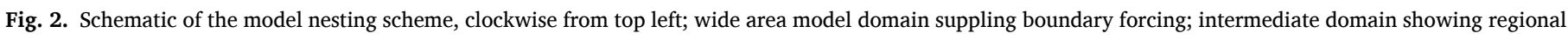

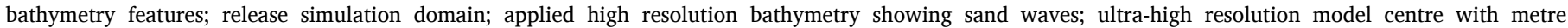
scale resolution.

\subsection{Release scenarios}

We assess the spread, dilution, and persistence of a number of realistic brine release scenarios, in terms of salinity and temperature, and further calculate dilution factors to enable the estimation of other chemical characteristics of the produced water such as oxygen levels and contaminants. Based on these results we estimate the impact potential from a range of scenarios and dispersion methods, including a combination of seabed, mid-depth, and sea surface discharges, across different seasons each with specific mixing characteristics.

Release scenarios are difficult to estimate a-priori, and brine characteristics are highly variable. We have taken a worst-case scenario approach here based on commercially sensitive supporting data in order to place upper constraints on impact potential. We have assumed a brine concentration of $258 \mathrm{PSU}$ at $56^{\circ} \mathrm{C}$ and a maximum discharge rate of 9.29 $\mathrm{Mt} / \mathrm{a}$ (equivalent of 160,000 barrels of freshwater a day by volume) via managed extraction. Further we assume that seabed production would be mediated via a number of brine extraction wells (e.g. four) spaced at some distance, which initial model experiments indicated do not interact. Therefore, a seabed discharge of 40,000 barrels per day is simulated. In order to test the effect of discharge at both the mid-depth and the sea surface, we assume a single emitter of 160,000 barrels of brine per day.

We further investigate smaller discharge rates approximating to an unmanaged seep scenario via an outcrop of the aquifer bearing strata, again some distance away from the other releases. Here we presume a total of 20,000 barrels per day as either a single source or as 10 diffuse sources of 2000 barrels per day. Mass equivalents are given in Table 1. In addition, a no-release baseline scenario is used for comparison.

Table 1

Release scenarios.

\begin{tabular}{llllcl}
\hline Scenario & $\begin{array}{l}\text { Release Rate } \\
\text { Mt/a }\end{array}$ & $\begin{array}{l}\text { Release Rate } \\
\text { barrels/day } \\
1\end{array}$ & $\begin{array}{l}\text { Salinity } \\
\text { PSU }\end{array}$ & $\begin{array}{c}\text { Temp } \\
{ }^{\circ} \mathrm{C}\end{array}$ & Release mode \\
2 & 9.29 & $\begin{array}{l}40,000 \\
160,000\end{array}$ & 258 & 56 & Seabed \\
3 & 9.29 & 160,000 & & & Surface \\
4 & 1.16 & 20,000 & & Mid-Depth \\
5 & $10 \times 0.116$ & $10 \times 2000$ & & & Seabed \\
& & & & Seabed \\
\hline
\end{tabular}

\subsection{UK coastal model}

The UK coastal shelf model (Fig. 2. top left) is utilised to set up the model domain and boundary forcing (Scottish Shelf Model, shelf wide domain, version 2.01, (De Dominicis et al., 2018)), forced by realistic tidal, current, thermal and wind driven mixing, with boundary conditions supplied by reanalysis simulations of the wider area. The bathymetry is set by data from the European Marine Observation and Data Network (EMODnet) and the North-West Shelf Operational Oceanographic System (NOOS), the latter, for the North Sea east of $0^{\circ} \mathrm{E}$, are interpolated onto the model mesh. The model has 20 equal vertical levels of terrain following sigma coordinates, each representing $5 \%$ of the water column depth. Forcing data including temperature, salinity and currents are defined at the model open boundaries, based on a year-long climatology representing average conditions between 1990 2014. Depth-resolved temperature, salinity and non-tidal current inputs are generated from the Atlantic Margin Model (Edwards et al., 2012; O'Dea et al., 2012) interpolated onto the FVCOM vertical mesh at the open boundary nodes. The tidal components (currents and elevation) have been generated from the TPXO global ocean tidal model (Egbert and Erofeeva, 2002), with eight primary (M2, S2, N2, K2, K1, O1, P1, Q1), two long period (Mf, Mm) and 3 non-linear (M4, MS4, MN4) harmonic constituents from a single year interpolated onto the FVCOM mesh at each of the open boundary nodes. Surface forcing (wind, heating, precipitation) is derived from ECMWF ERA-Interim model configured for the UK shelf (Dee et al., 2011). River freshwater data is sourced from Grid 2 Grid (1962-2011) obtained from the Centre of Ecology (CEH) (Bell et al., 2007; Cole and Moore, 2009). The hydrodynamics are run for a full year, with outputs recorded at the boundaries of the smaller domains in Fig. 2, providing the nested forcing data.

\subsubsection{Local domain}

The nested domains used for the release scenarios are bespoke to this study, with inputs for the nested domain taken directly from the larger domain to again represent present-day climatology. The model resolution varies from $2.5 \mathrm{~km}$ at the boundaries to $5 \mathrm{~m}$ at the centre, with 20 equal layer depths as sigma coordinates. The computational time step is $0.15 \mathrm{~s}$, and the output frequencies are hourly over a single year. The first 6 months are treated as spin up to allow the background hydrodynamic properties to reach a quasi-steady-state (Isik, 2013). The mesh size at the 
release site is approximately $5 \mathrm{~m}$, giving an area of $25 \mathrm{~m}^{2}$, and with a height of $2.5 \mathrm{~m}$, giving the initial receiving volume of $62.5 \mathrm{~m} 3$. Hence there is an immediate dilution of the brine properties within the model. In reality there would be a gradient from the undiluted brine properties at the injection pipeline terminus to the values reported here, a few metres distant.

The horizontal currents in the nested region will greatly affect the plume concentration and dispersion rate. Higher currents will spread the plume over a larger area, but at the same time provide greater mixing, giving lower concentrations. Estimates of impact are therefore presented at periods of maximum and minimum currents. The seabed, mid-depth, and surface mean daily currents, along with seawater temperature fluctuations from a physics only simulation can be seen in Fig. 3. The differences in daily mean currents at the release location and outcrop are found to be negligible. Given the plume will impact mostly on the seabed due to high density waters, the maximum daily mean current experienced on the seabed is on the 18th of September, and minimum daily mean current experienced on the seabed is on the 12th August. Detailed results for these dates are analysed here to enable the assessment of currents on the plume dynamics.

\subsection{Impact metrics}

For the purposes of this study a set of stringent impact thresholds were identified:

- Salinity: A salinity greater than 36.75 PSU, or a or a $5 \%$ increase over regional mean salinity is used as a conservative toxicological threshold, based on guidelines related to the permitting of Seawater Reverse Osmosis (desalination) plants (de-la-Ossa-Carretero et al., 2016; Frank et al., 2017; Lykkebo Petersen et al., 2019; Sánchez-Lizaso et al., 2008).

- Temperature: In terms of temperature, the largest short-term changes in ambient temperature occur over the thermocline, the vertical structure imposed by surface heating, and lie in the range of $2-5{ }^{\circ} \mathrm{C}$, which are routinely tolerated by diurnally migrating species. We have considered an increase of $5{ }^{\circ} \mathrm{C}$ over background as a lower threshold for response.

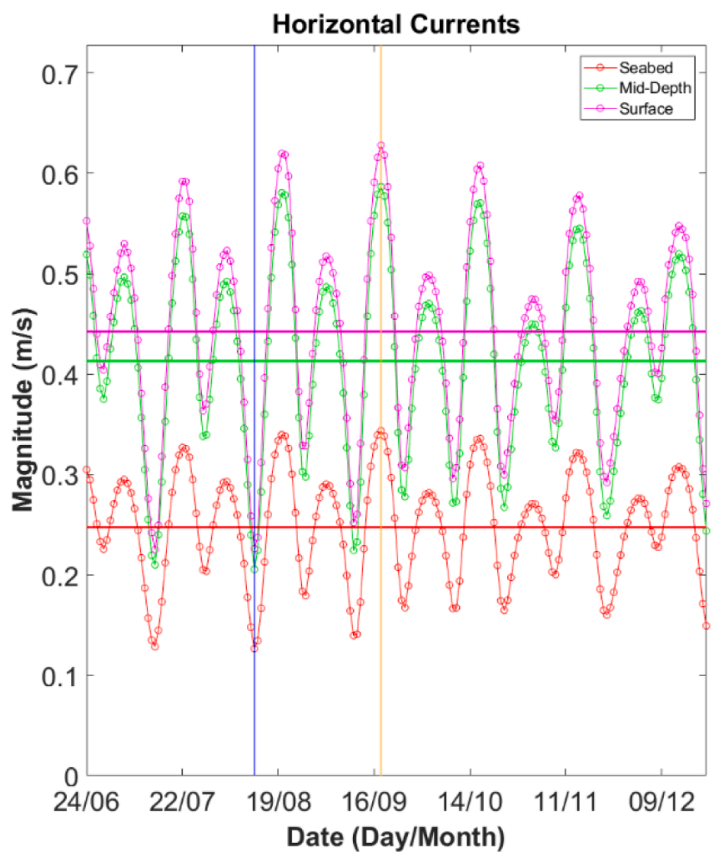

- Contaminants: Specific thresholds would depend on contaminant concentration within the brine in combination with the relevant Predicted No Effect Concentration (PNEC - the concentration at which the contaminant is considered benign). We report on a range of dilution factors up to 5000 fold, equivalent to a salinity of 0.045 PSU above background. This would be sufficient to reduce for example a hypothetical extreme contaminant concentration of $\sim 25 \mathrm{mg} / 1$ to a hypothetical PNEC of $5.0 \mu \mathrm{g} / \mathrm{l}$ as an extreme worstcase scenario.

- Oxygen: With respect to oxygen, the European Union Water Framework Directive (WFD) defines high water quality as greater than $7 \mathrm{mg} / \mathrm{l}$, above $4.7 \mathrm{mg} / \mathrm{l}$ as good, above $2 \mathrm{mg} / \mathrm{l}$ as moderate with severe hypoxia below $2 \mathrm{mg} / \mathrm{l}$ for near shore waters. OSPAR define $6.0 \mathrm{mg} / \mathrm{l}$ as a the upper threshold for hypoxia in shelf waters. (Queste et al., 2013). Presuming completely anoxic brine and a mean seawater oxygen concentration of $7 \mathrm{mg} / \mathrm{l}, 6.0 \mathrm{mg} / \mathrm{l}$ equates to a dilution factor of 7 and $2 \mathrm{mg} / 1$ to a dilution factor of 1.4 .

From this, it is clear that a contaminant related threshold would likely be the first threshold to be breached.

\section{Results}

We find that the natural mixing processes dominated by tidal flow, in addition to entrainment from the negatively buoyant hypersaline plumes, generally disperse hypersaline plumes rapidly. Even at this relatively shallow North Sea depth of $\sim 50 \mathrm{~m}$ any potential impacts in the water column are well constrained, in the order of $10^{\prime} \mathrm{s}-100^{\prime} \mathrm{s}$ of meters in any direction depending on disposal scenario (Figs. 4-7), with the vertical position of the plume dependant on the release scenario and tidal current strength, and with seabed impacts presented in Table 2.

As the plume oscillates in space, driven by the tidal cycle (Figs. 5 and 6), a fluctuating signal is detected at any given point. Therefore, the results are further analysed by an integration of the area impacted over a $24 \mathrm{~h}$ period. Snapshots of the periods of maximum and minimum currents (on the 18th September and 12th August respectively), are analysed to enable the assessment of hydrodynamic variability on the plume. Elevated temperatures as a result of disposal are highly localised

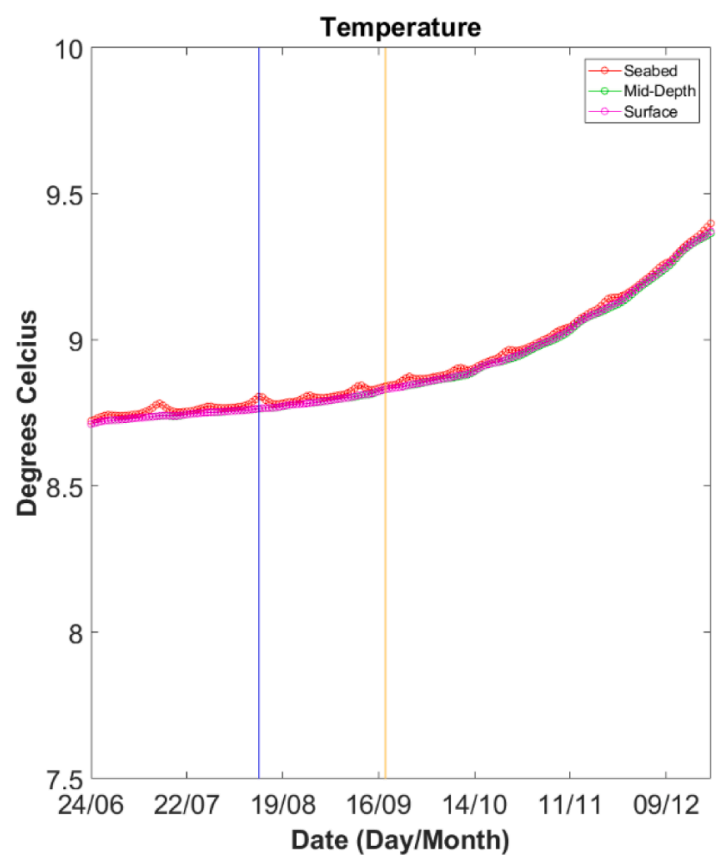

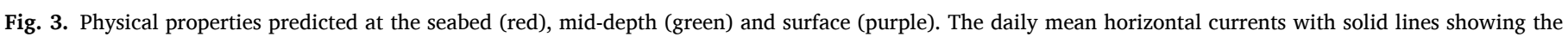

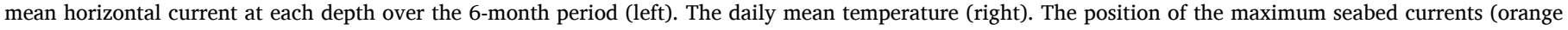
vertical line - 18th of September) and minimum seabed currents (blue vertical line - 12th of August) are highlighted on both. 

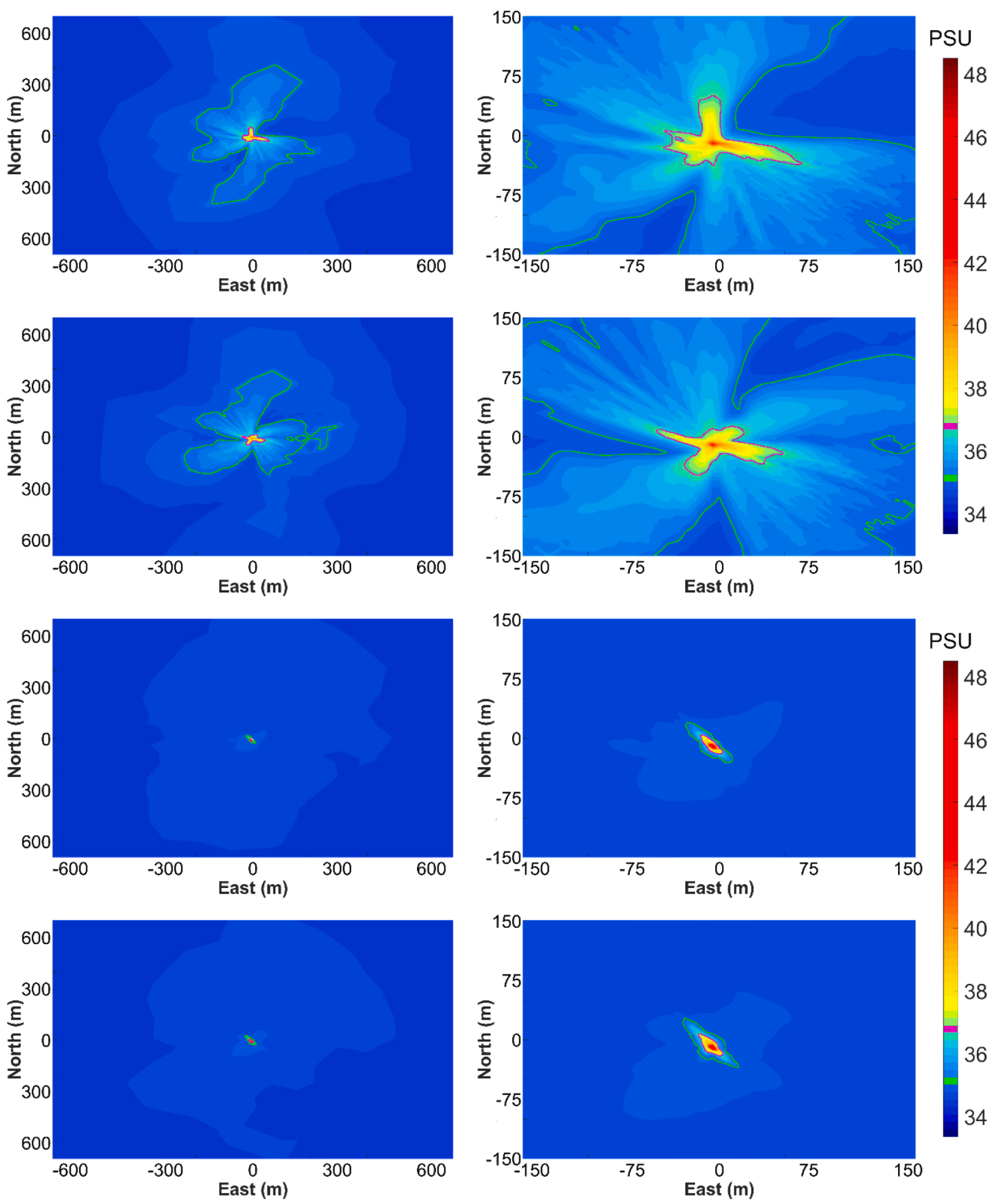

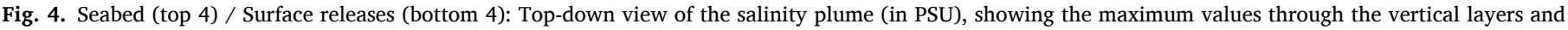

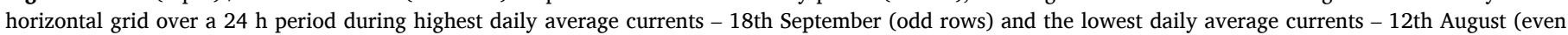

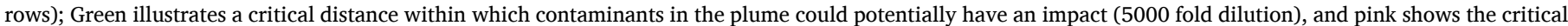

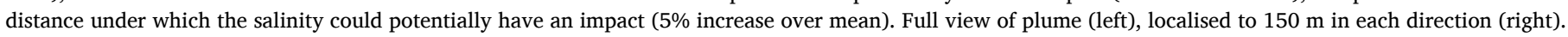

and limited to less than $5{ }^{\circ} \mathrm{C}$ within the model when analysed in the smallest $5 \times 5 \mathrm{~m}$ grid. Similarly, oxygen depletion is highly localised, with no thresholds exceeded beyond this scale. This means that values between the source concentrations and these thresholds are predicted to only occur within less than $5 \mathrm{~m}$ from the source whilst being heavily diluted.

\subsection{Seabed release (40,000 barrels/day)}

For the seabed releases, the horizontal areas that breech the worst case contaminant related threshold (1:5000 dilution) through the tidal cycle in the water column are shown in the top four images in Fig. 4 (green outline) and a 3D representation of the plume shown in Fig. 5. The contaminants can be seen to impact a distance up to $500 \mathrm{~m}$ away from the source, impacting an area on the seabed of up to $0.58 \mathrm{~km}^{2}$ over the major tidal cycle as shown in Table 2. The salinity threshold is breeched at distances up to $100 \mathrm{~m}$ from the source, and beyond the initial source the temperature change dilutes to within natural variability very quickly and is considered too small to have any impact. No significant accumulation of hypersaline waters is predicted within the 

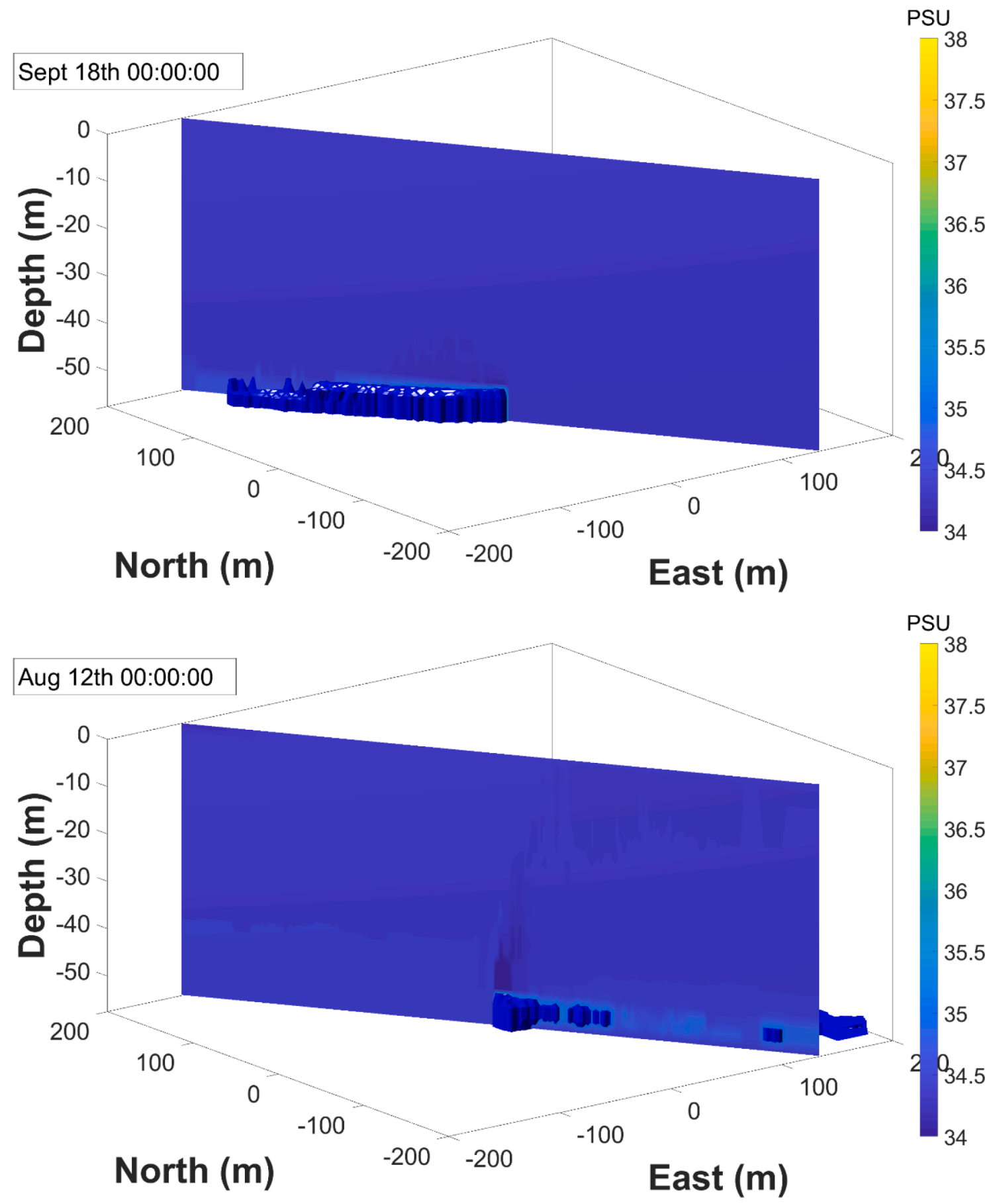

Fig. 5. 3D representation of the seabed release scenario (40,000 barrels/day), with a $2 \mathrm{D}$ slice to show changes away from the plume, comparing the plume on the 18th September (left), and the lowest daily currents on the 12th August (right). 3D regions indicate contaminants exceeding the dilution factor threshold of 5000, with the colour for the 3D and 2D slice showing the predicted salinity (For interpretation of the references to color in this figure legend, the reader is referred to the web version of this article.).

sand wave troughs.

\subsection{Sea surface release (160,000 barrels/day)}

For the surface release, the horizontal areas that breech the contaminant threshold through the tidal cycle in the water column are shown in the bottom four images in Fig. 4, and a 3D representation of the plume shown in Fig. 6, with no significant accumulation of hypersaline waters within the sand wave troughs. The contaminants can be seen to impact a distance less than $50 \mathrm{~m}$ away from the source, in an area on the seabed of up to $1.6 \times 10^{-3} \mathrm{~km}^{2}$ over the major tidal cycle as shown in Table 2 . The salinity threshold is breeched only at distances less than 20 $\mathrm{m}$ from the source. As the previous case, the impact of the temperature change is too small to have any impact.

\subsection{Mid-Depth release (160,000 barrels/day)}

For the mid-depth release, the contaminants impact a distance less than $125 \mathrm{~m}$ away from the source in the water column, and can be seen to impact an area on the seabed of up to $1.9 \times 10^{-2} \mathrm{~km}^{2}$ over the major 

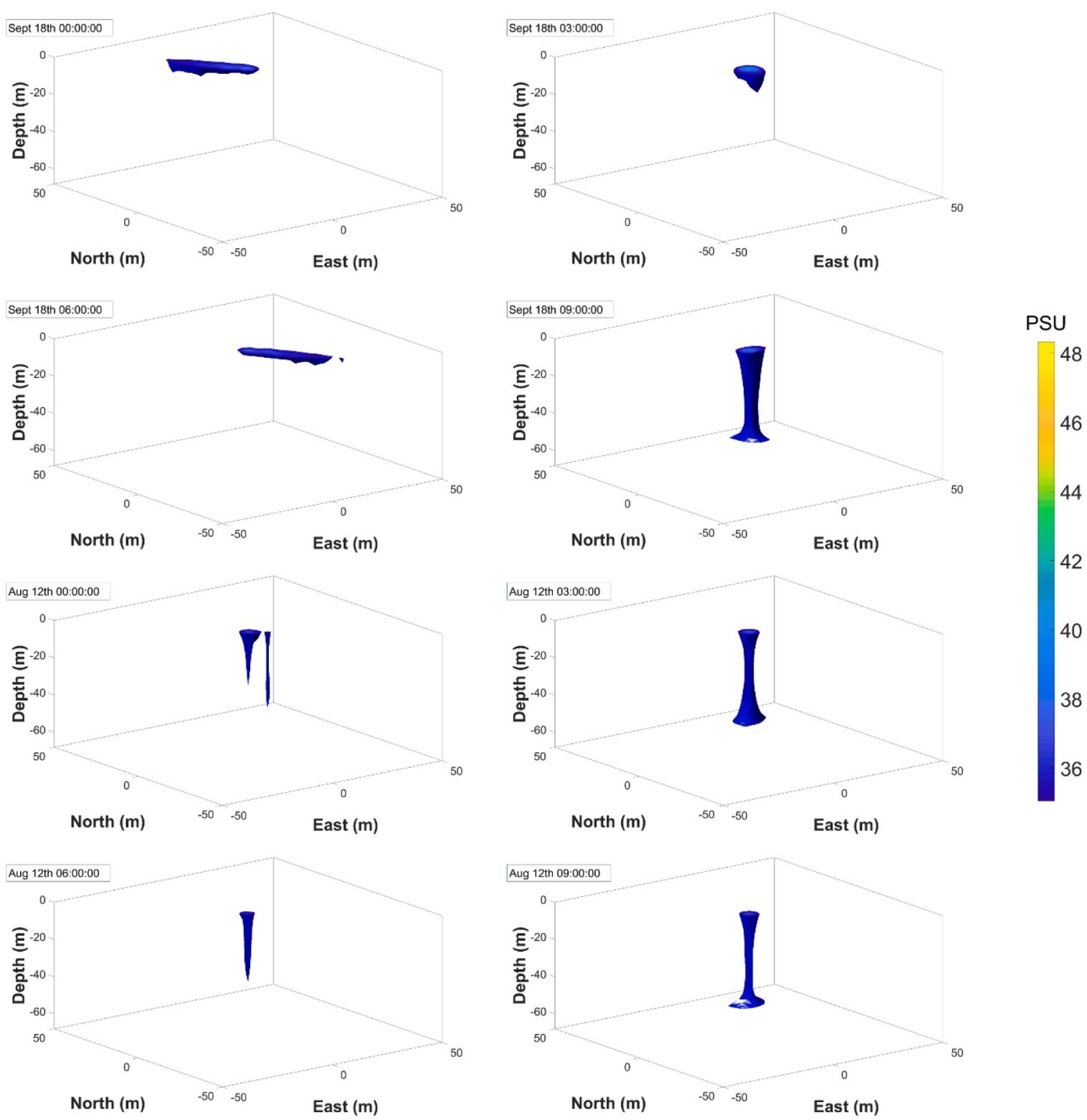

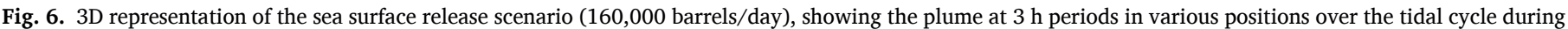

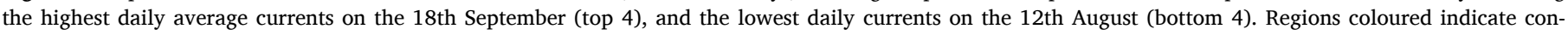

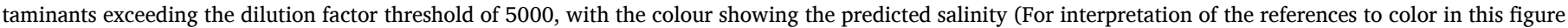
legend, the reader is referred to the web version of this article.).

tidal cycle as shown in Table 2 . The salinity threshold is breeched only at distances less than $20 \mathrm{~m}$ from the source. As these findings lie between the two extreme cases above, illustrations for this case are not presented. Like the previous cases, the impact of the temperature change is too small to have any impact.

\subsection{Outcrop $(20,000$ barrels/day)}

\subsubsection{Outcrop single point seep}

As before, the horizontal areas that are impacted by contaminant related impact through the tidal cycle in the water column are shown in the top 4 images in Fig. 7. The contaminant threshold breeches occur at distances less than $500 \mathrm{~m}$ away from the source, in an area on the seabed of up to $0.72 \mathrm{~km}^{2}$ over the major tidal cycle as shown in Table 2 . The salinity threshold breech occurs at distances less than $20 \mathrm{~m}$ from the source. As the previous cases, the impact of the temperature change is considered too small to cause an impact.

\subsubsection{Outcrop multiple point seep}

The horizontal areas that breech the salinity and contaminant thresholds through the tidal cycle in the water column are shown in the bottom 4 images in Fig. 7. It can be seen that the salinity threshold cannot be detected (within the $5.0 \mathrm{~m}$ resolution of the model), and the contaminants threshold breech is confined to a distance less than $20 \mathrm{~m}$ from the source, impacting an area on the seabed of up to $8.6 \times 10^{-3}$ $\mathrm{km}^{2}$ over the major tidal cycle as shown in Table 2. As the previous cases, the impact of the temperature change is too small to have any noticeable impact.

\section{Discussion}

In this study we have deliberately taken a worst-case scenario approach, by simulating the upper end of the scenario space, coupled with very stringent thresholds of potential impact, with a relatively low depth North Sea release. The findings are summarised in Fig. 8 for 

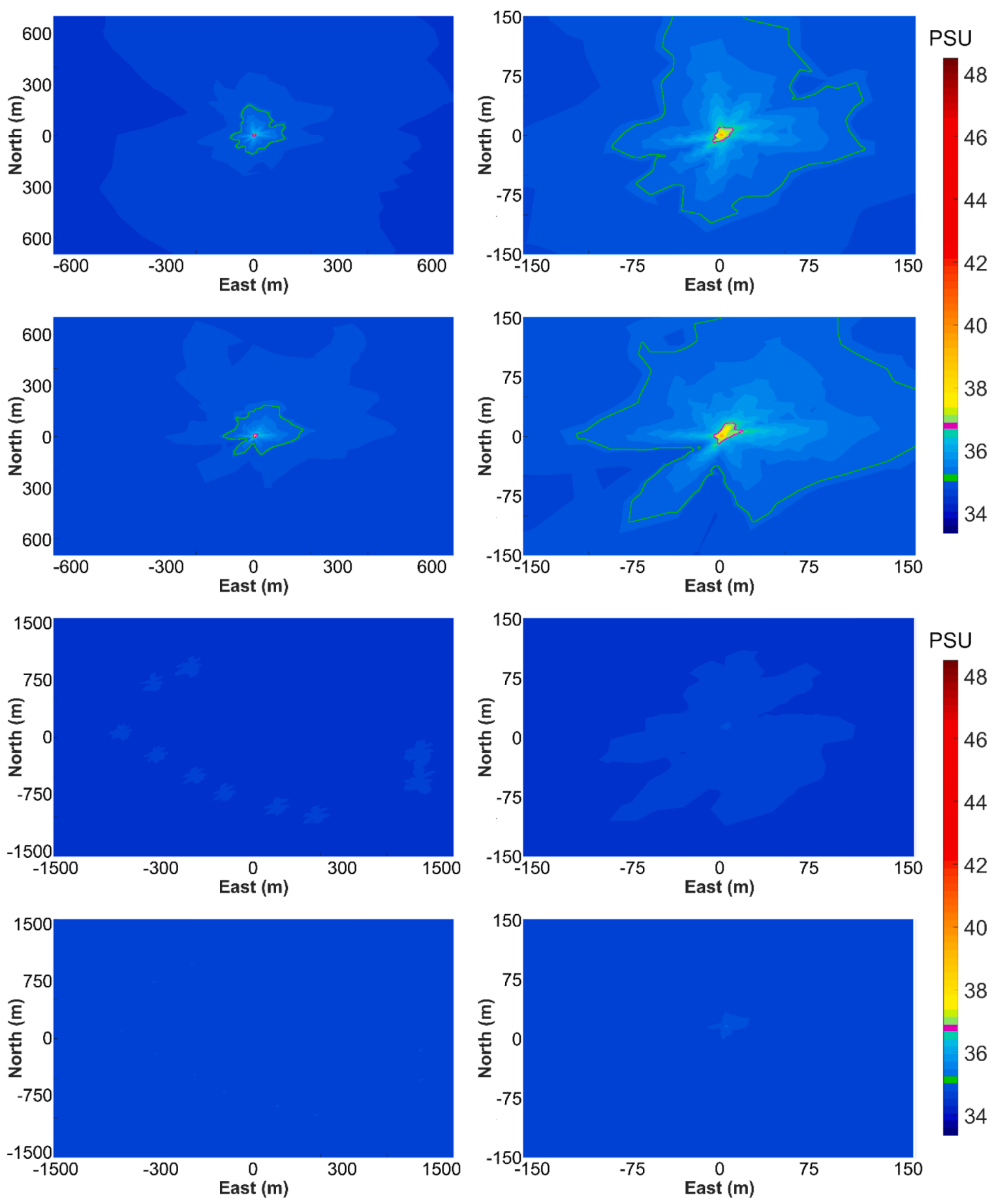

Fig. 7. Single outcrop flow (top 4) / Multiple outcrop flow (bottom 4): Top-down view of the salinity plume (in PSU), showing the maximum values through the vertical layers and horizontal grid over a $24 \mathrm{~h}$ period during highest daily average currents - 18th September (odd rows) and the lowest daily average currents - 12th August (even rows); Green shows the critical distance under which contaminants in the plume could potentially have an impact, and pink shows the critical distance under which the salinity could potentially have an impact. Full view of plume (left), localised to $300 \mathrm{~m}$ in each direction (right) (For interpretation of the references to color in this figure legend, the reader is referred to the web version of this article.).

threshold exceeding areas on the seabed in terms of the worst case contaminates (1:5000 dilution threshold). Areas range up to $0.6 \mathrm{~km}^{2}$ for a single seabed release point, in comparison with up to $1.9 \times 10^{-2}$ and $1.6 \times 10^{-3} \mathrm{~m}^{2}$ in the larger mid-depth and surface single releases respectively. In terms of the outcrop, a threshold exceeding area of up to $0.72 \mathrm{~km}^{2}$ from a single seep is predicted. If this rate is spread over more points, the potentially impacted area drops to a maximum of $8.6 \times 10^{-3}$ $\mathrm{km}^{2}$. Thermal impacts have been shown to be less than $3{ }^{\circ} \mathrm{C}$ in all cases and therefore negligible, and saline impacts occur over smaller distances/areas than the contaminants.

The largest potential impact is predicted from the seabed release, with a mean impacted seabed area of $0.25 \mathrm{~km}^{2}$ for a single 40,000 barrel/day release. However, assuming four release points were to be considered together giving the same release rate as the surface release, this area would be 4 times larger, with a potential maximum seabed impact area of $\sim 2.3 \mathrm{~km}^{2}$.

The major finding is that when comparing the seabed release above (at 40,000 barrel/day) with mid-depth or surface releases (at 160,000 
Table 2

Summary of predicted impacts on the seabed.

\begin{tabular}{|c|c|c|c|c|c|}
\hline Scenario & $\begin{array}{l}\text { Release } \\
\text { Rate } \\
\text { (barrels/ } \\
\text { day) }\end{array}$ & $\begin{array}{l}\text { Release } \\
\text { mode }\end{array}$ & $\begin{array}{l}\text { Maximum } \\
\text { Impact } \\
\text { Area* }\left(\mathrm{m}^{2}\right)\end{array}$ & $\begin{array}{l}\text { Max Salinity } \\
\text { Deviation** } \\
\text { (PSU) }\end{array}$ & $\begin{array}{l}\text { Max Temp } \\
\text { Deviation** } \\
\left({ }^{\circ} \mathrm{C}\right)\end{array}$ \\
\hline 1 & 40,000 & Seabed & $5.8 \times 10^{5}$ & 13.96 & 2.95 \\
\hline 2 & 160,000 & Surface & $1.6 \times 10^{3}$ & 1.29 & 0.29 \\
\hline 3 & 160,000 & $\begin{array}{l}\text { Mid- } \\
\text { Depth }\end{array}$ & $1.9 \times 10^{4}$ & 2.49 & 0.54 \\
\hline 4 & 20,000 & Seabed & $7.2 \times 10^{5}$ & 9.79 & 2.08 \\
\hline 5 & $\begin{array}{l}10 \times \\
2000\end{array}$ & Seabed & $8.6 \times 10^{3}$ & 1.85 & 0.40 \\
\hline
\end{tabular}

*based on a 5000 -fold dilution, **mean values across $5 \times 5 \mathrm{~m}$ grid cells.

barrel/day), the mean affected areas in the water column are reduced to $1.2 \times 10^{-3} \mathrm{~km}^{2}$ and $4.3 \times 10^{-4} \mathrm{~km}^{2}$ respectively. This means that even with the four times greater release rate, the average impacted area in the water column is $\sim 20$ times less at the mid-depth release, and $\sim 600$ times less at the surface release. This large effect is due to larger currents higher in the water column (shown in Fig. 3 ) and the mixing experienced during the vertical drop (shown in Fig. 6 when comparing the high tidal current and low tidal current plumes) dispersing and diluting the hypersaline waters more rapidly. With the release over a water column of only $50 \mathrm{~m}$ depth, this dilution has the potential to increase further in deeper water columns.

As shown in Fig. 6 any impact from sea surface releases is minimal, and only detectable on the seabed during low tidal currents, remaining within 10-15 $\mathrm{m}$ of the source before being diluted through the horizontal tidal flows beyond detection. Mixing due to the vertical drop from high density hypersaline waters has a large role to play, with the impact found to be in a similar order to that of the mean water current. When the tidal currents are low, the dense hypersaline waters dominate the flow, allowing the impacts to reach the seafloor providing a vertical plume. However, in strong tides, these currents dominate over the highdensity hypersaline waters providing a horizontal plume as can be seen in Fig. 6.

Another impact of the tidal currents is the effect on stratification from the seabed release. Fig. 5 (top) shows that during high tidal currents the salinity away from the plume remains at background values. However, Fig. 5 (bottom) shows that during low tidal currents, slight stratification is noticed around the leakage region with salinity increases of up to 0.025 beyond background values reaching up to $20 \mathrm{~m}$ height from the seabed. Therefore, in locations where the tidal currents are low this may be a potential concern and further simulations would be required to investigate specific locations.

The impacts higher in the water column away from the seabed in the sea surface and mid-depth releases are less of a concern, measuring in the order of $10 \mathrm{~s}$ of meters, with the large currents most species would pass by in a matter of seconds to a minute reducing exposure. Whereas on the seabed, many species: organisms, plants and habitats are immobile or restricted increasing their impact risk. With the choice of location of release, a baseline study would be recommended to assess the biodiversity and vulnerability of in situ fauna.

Comparing the mean daily currents and the impacted area, generally a bigger impact area can be seen with the lower daily mean currents when comparing Fig. 8 with in Fig. 3, this is because of the mixing and dispersion at the higher currents. To summarise the results, the largest plumes from each the worst-case scenarios are shown overlaid in Fig. 9.

In terms of the outcrop scenario, there is no control over how many seep points may occur, if any, or what area they might cover. But the analysis shows that the impacted area is greatly reduced as the number of seep points increases.

Of necessity we have made several assumptions in this work. For example, the release configurations tested are rudimentary and may be nuanced in practice by number of injection points, pipeline diameter or inducing rapid flow to enhance mixing, all with some effect on cost.. We have assumed likely maximum discharge rates and used an extreme assumption of contaminant concentration. Any reduction of these values would significantly decrease the potentially impacted area. The model presented here is able to resolve horizontally to a $5 \mathrm{~m}$ scale at the release

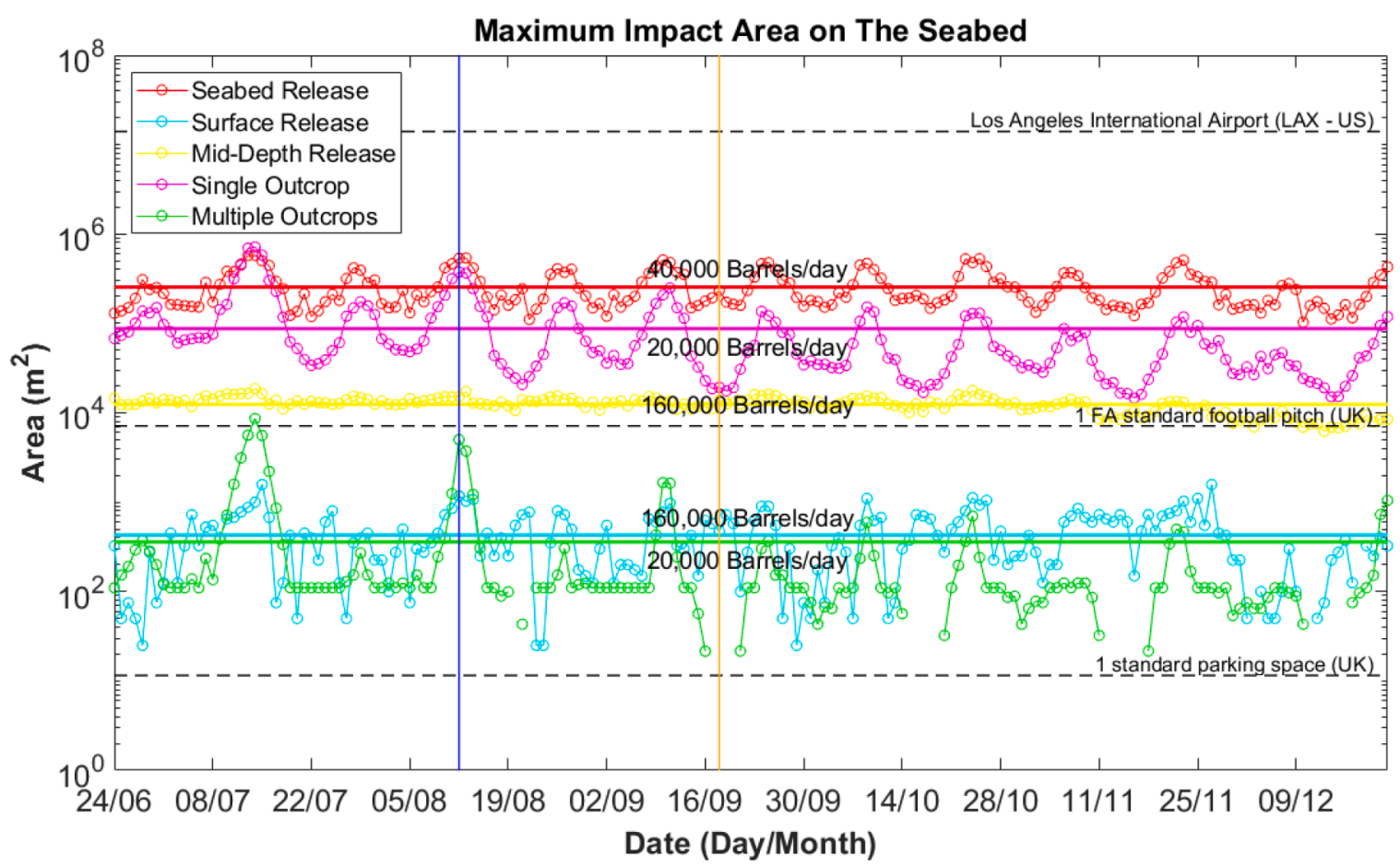

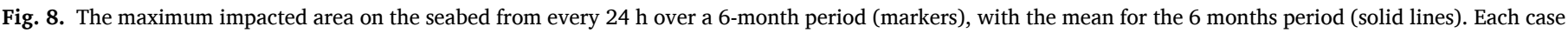

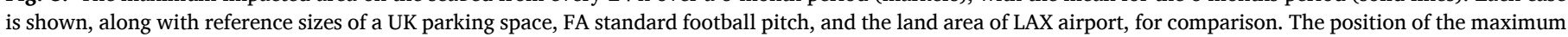

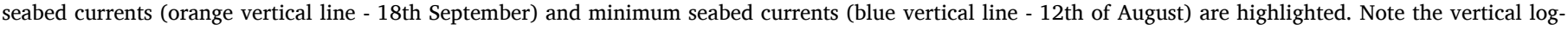
arithmic scale (For interpretation of the references to color in this figure legend, the reader is referred to the web version of this article.). 


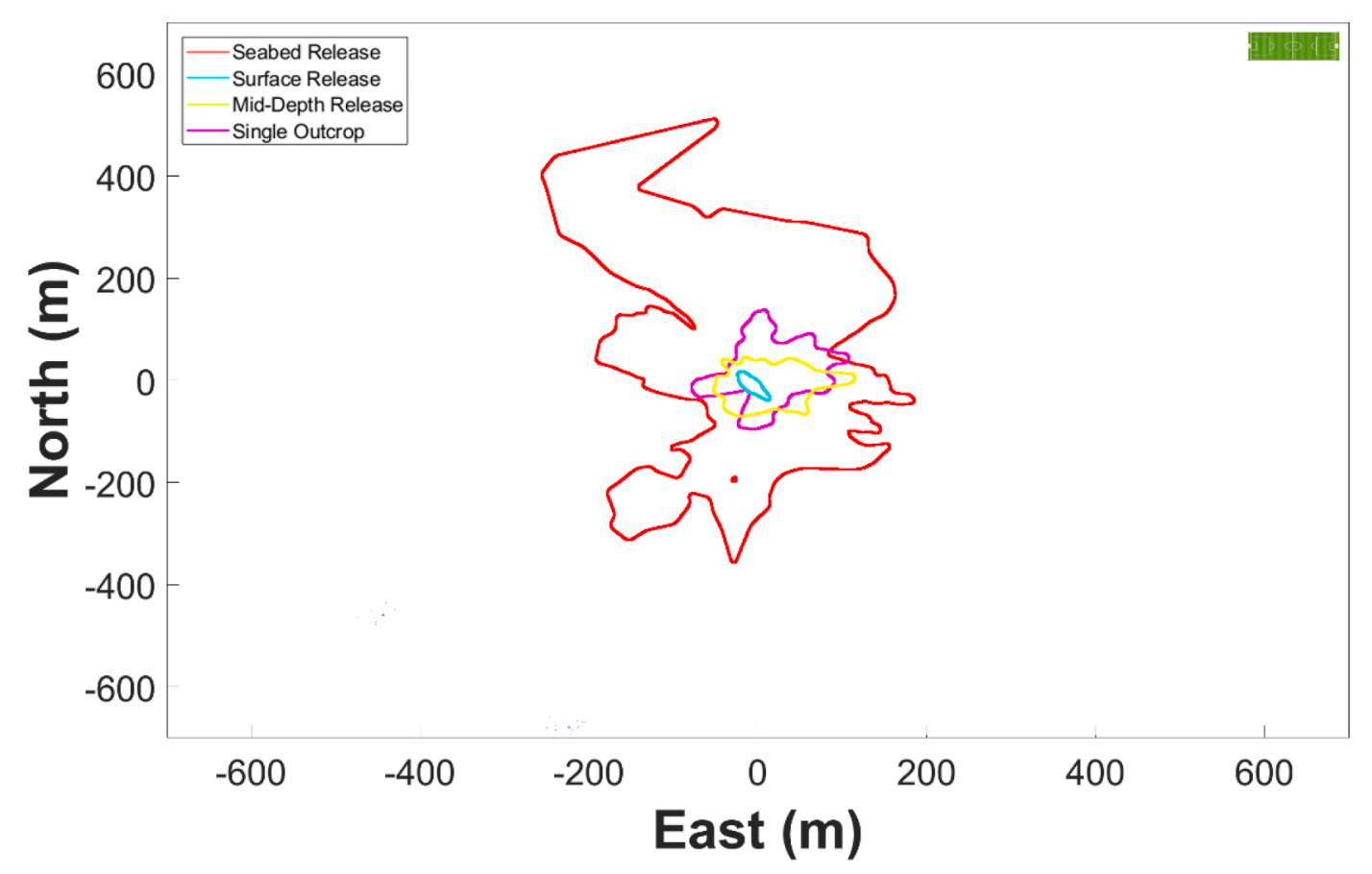

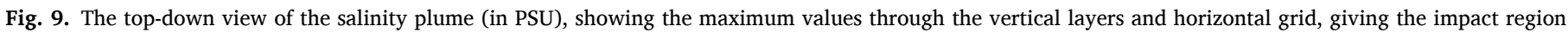

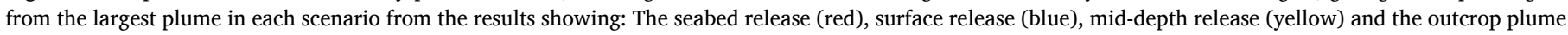

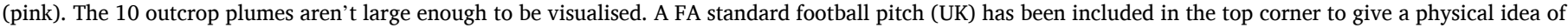
scale (For interpretation of the references to color in this figure legend, the reader is referred to the web version of this article.).

epicentre, with the extreme gradients from discharge point over the first five metres unresolved. However, as the purpose of this work was to assess regional impact potential. Impacts on the scale of a few square metres are generally considered negligible, especially once assessed against existing anthropogenic impacts on the marine environment.

\section{Conclusions}

Rather than an environmental impact assessment per se, with this work we attempt to establish bounds on the environmental impact potential that may arise from reservoir pressure management interventions. In relatively shallow well mixed environments natural mixing processes, dominated by tidal flow, disperse hypersaline plumes rapidly. For all the scenarios tested here the impact potential with respect to elevated temperature or hypoxia is highly localised and unlikely to be consequential for the environment. Plumes of elevated salinity are restricted to length scales of 10-100 s of meters for the scenarios tested with no significant accumulation within the sand wave troughs.

There is a clear affect arising from the mode of release, with disposal at the mid-depth and sea surface leading to far quicker dispersion and smaller seabed footprints due to dilution in the vertical drop. Further the area impacted is reduced as the number of release points increases. Contaminants hypothetically requiring dilutions of order $10^{3}$ pose the largest impact concern. Contaminants can also accumulate within sediments and biota which requires further consideration. In operational reality, production of waters may be at lower rates and impact areas relatively reduced. Specific outcomes would be affected by in-situ mixing at the time of release and as such these model predictions provide estimates of impact scale rather than absolute predictions.

The dispersal rate and ultimate impact scale of brine disposal will be dependent on the degree of hydrodynamic mixing particular to the given site. These results suggest that direct disposal of brines into seawater will have a limited salinity or temperature impact in regions such as the North Sea that experience strong tidal forcing and are generally well mixed. The footprint of contaminants is the largest impact prediction, suggesting that these concentrations may be the controlling factor from an ecosystem point of view. However, the results may not extrapolate to sites where mixing is limited.

The impacts would depend on what contaminants, nutrients and concentrations of gasses were present in the surrounding and hypersaline waters, along with what marine species are present in the vicinity of the release. These are unknowns in this preliminary stage of the investigation until reservoir samples and a good baseline study are analysed prior to any release taking place. The results presented here however provide an indication of the distances that could be impacted before the concentration is diluted by 5000 times that of the source concentration.

Three recommendations follow from this study

- The mode of release (seabed, mid-depth, and surface) has a significant impact on dispersion. Higher release points could be considered as these minimise the dilution length scales.

- If disposal of hypersaline brines is enacted; monitoring may be effectively achieved by using standard temperature-salinity sensors deployed on the sea floor, coupled with knowledge of contaminant concentrations to verify the dilution factor. This would allow monitoring of both seabed water releases and high salinity surface releases. The recommended positioning is at a distance of $5-50 \mathrm{~m}$ laterally from the discharge point, aligned with the dominant tidal axis based on the findings in a relatively shallow North Sea scenario (50 $\mathrm{m}$ depth). Sampling should cover at least one tidal cycle and ideally also sample a spring-neap cycle. Model results suggest that after a few days disposal the plume has reached a quasi-steady state. Periodic resampling (every few months) is recommended for added assurance.

- Further work addressing different releases including different depths and lower salinity brines, where the effects may remain in the upper water column, and varied contaminant concentrations based on measured in-situ data, may be beneficial. In particular this study does not consider specific ecological vulnerabilities nor the potential 
for long term accumulation of contaminants in the sediments or food chain. Such studies would be recommended.

\section{Declaration of Competing Interest}

The authors declare that they have no known competing financial interests or personal relationships that could have appeared to influence the work reported in this paper.

\section{Acknowledgements}

The authors acknowledge the support from the ACT Pre-ACT project (Project No. 271497) funded by RCN (Norway), Gassnova (Norway), BEIS (UK), RVO (Netherlands), and BMWi (Germany) and co-funded by the European Commission under the Horizon 2020 programme, ACT Grant Agreement No 691712. Along with the UK Research and Innovation National Environmental Research Council (UKRI-NERC) National Capability funding program CLASS (NE/R015953/1).

Generation of model inputs for FVCOM used the FVCOM MATLAB toolbox (Cazenave et al., 2019). With colour maps, graphs and figures produced by MATLAB (MATLAB, 2017).

\section{References}

Abbaspour, M., Javid, A.H., et al., 2012. Investigation of lake drying attributed to climate change. Int. J. Environ. Sci. Technol. 9, 257-266. https://doi.org/10.1007/s13762012-0031-0.

Ali Bek AbdelRhman, M., Cowles, G., 2018. a three-dimensional circulation model of Lake Bardawil, Egypt. Handbook of Environmental Chemistry. https://doi.org/ $10.1007 / 6982018279$.

Barry, R.G., Hall-McKim, E.A., 2018. Polar Environments and Global Change. Cambridge University Press.

Bell, V.A., Kay, A.L., Jones, R.G., Moore, R.J., 2007. Development of a high resolution grid-based river flow model for use with regional climate model output. Hydrol. Earth Syst. Sci. 11, 532-549. https://doi.org/10.5194/hess-11-532-2007.

Buscheck, T.A., Bielicki, J.M., White, J.A., Sun, Y., Hao, Y., Bourcier, W.L., Carroll, S.A., Aines, R.D., 2016. Pre-injection brine production in $\mathrm{CO}_{2}$ storage reservoirs: an approach to augment the development, operation, and performance of CCS while generating water. Int. J. Greenh. Gas Control 54, 499-512. https://doi.org/10.1016/ j.ijggc.2016.04.018.

Cazenave, P., Torres, R., O’Hara Murray, R., Amoudry, K., Liu, C., 2019. pwcazenave/ fvcom-toolbox: relatively minor fixes with improvements and bug squashing. Zenodo. https://doi.org/10.5281/zenodo.2573959.

Chamanmotlagh, F., Safaie, A., 2021. Drivers of spatio-temporal salinity distribution in a hypersaline lake (No. EGU21-10641). In: Proceeding of the Presented at the EGU21, Copernicus Meetings. https://doi.org/10.5194/egusphere-egu21-10641.

Chen, C., Huang, H., Beardsley, R.C., Liu, H., Xu, Q., Cowles, G., 2007. A finite volume numerical approach for coastal ocean circulation studies: comparisons with finite difference models. J. Geophys. Res. 112 https://doi.org/10.1029/2006JC003485.

Cole, S.J., Moore, R.J., 2009. Distributed hydrological modelling using weather radar in gauged and ungauged basins. Adv. Water Resour. Weather Radar Hydrol. 32, 1107-1120. https://doi.org/10.1016/j.advwatres.2009.01.006.

Corporation, W.B., 1972. Manual of Clinical Enzyme Measurements. Worthington Diagnostics.

Dabestani, M., Mohammad Mahdizadeh, M., Azizpour, J., 2020. Comparison of surface salinity of Persian Gulf water using field data and FVCOM numerical model. J. Oceanogr. 11, 81-87.

De Dominicis, M., Murray, R.O., Gallego, A., Wolf, J., 2018. The Scottish shelf model 1990 -2014 climatology 2.01. 10.7489/12037-1.

Dee, D.P., Uppala, S.M., Simmons, A.J., Berrisford, P., Poli, P., Kobayashi, S., Andrae, U., Balmaseda, M.A., Balsamo, G., Bauer, P., Bechtold, P., Beljaars, A.C.M., Berg, L.V.D., Bidlot, J., Bormann, N., Delsol, C., Dragani, R., Fuentes, M., Geer, A.J., Haimberger, L., Healy, S.B., Hersbach, H., Hólm, E.V., Isaksen, L., Kållberg, P., Köhler, M., Matricardi, M., McNally, A.P., Monge-Sanz, B.M., Morcrette, J.J., Park, B.K., Peubey, C., Rosnay, P.de, Tavolato, C., Thépaut, J.N., Vitart, F., 2011. The ERA-Interim reanalysis: configuration and performance of the data assimilation system. Q. J. R. Meteorol. Soc. 137, 553-597. https://doi.org/10.1002/qj.828.

de-la-Ossa-Carretero, J.A., Del-Pilar-Ruso, Y., Loya-Fernández, A., Ferrero-Vicente, L.M., Marco-Méndez, C., Martinez-Garcia, E., Sánchez-Lizaso, J.L., 2016. Response of amphipod assemblages to desalination brine discharge: impact and recovery. Estuar. Coast. Shelf Sci. 172, 13-23. https://doi.org/10.1016/j.ecss.2016.01.035.

Edenhofer, O., Intergovernmental Panel on Climate Change, 2014. Climate Change 2014: Mitigation of Climate change: Working Group III Contribution to the Fifth assessment Report of the Intergovernmental Panel On Climate Change. Cambridge University Press.

Edwards, K.P., Barciela, R., Butenschön, M., 2012. Validation of the NEMO-ERSEM operational ecosystem model for the North West European continental shelf. Ocean Sci. 8, 983-1000. https://doi.org/10.5194/os-8-983-2012.
Egbert, G.D., Erofeeva, S.Y., 2002. Efficient inverse modeling of barotropic ocean tides. J. Atmos. Ocean. Technol. 19, 183-204. https://doi.org/10.1175/1520-0426(2002) 019<0183:EIMOBO > 2.0.CO;2.

Fouillac, A.M., Grath, J., Ward, R., 2009. Groundwater Monitoring. John Wiley \& Sons.

Frank, H., Rahav, E., Bar-Zeev, E., 2017. Short-term effects of SWRO desalination brine on benthic heterotrophic microbial communities. Desalination 417, 52-59. https:// doi.org/10.1016/j.desal.2017.04.031.

Friedlingstein, P., O’Sullivan, M., Jones, M.W., Andrew, R.M., Hauck, J., Olsen, A., Peters, G.P., Peters, W., Pongratz, J., Sitch, S., Le Quéré, C., Canadell, J.G., Ciais, P., Jackson, R.B., Alin, S., Aragão, L.E.O.C., Arneth, A., Arora, V., Bates, N.R., Becker, M., Benoit-Cattin, A., Bittig, H.C., Bopp, L., Bultan, S., Chandra, N., Chevallier, F., Chini, L.P., Evans, W., Florentie, L., Forster, P.M., Gasser, T. Gehlen, M., Gilfillan, D., Gkritzalis, T., Gregor, L., Gruber, N., Harris, I., Hartung, K., Haverd, V., Houghton, R.A., Ilyina, T., Jain, A.K., Joetzjer, E., Kadono, K., Kato, E., Kitidis, V., Korsbakken, J.I., Landschützer, P., Lefèvre, N., Lenton, A., Lienert, S., Liu, Z., Lombardozzi, D., Marland, G., Metzl, N., Munro, D.R., Nabel, J.E.M.S., Nakaoka, S.I., Niwa, Y., O'Brien, K., Ono, T., Palmer, P.I., Pierrot, D., Poulter, B., Resplandy, L., Robertson, E., Rödenbeck, C., Schwinger, J., Séférian, R., Skjelvan, I., Smith, A.J.P., Sutton, A.J., Tanhua, T., Tans, P.P., Tian, H., Tilbrook, B., van der Werf, G., Vuichard, N., Walker, A.P., Wanninkhof, R., Watson, A.J., Willis, D., Wiltshire, A.J., Yuan, W., Yue, X., Zaehle, S., 2020. Global carbon budget 2020. Earth Sys. Sci. Data 12, 3269-3340. https://doi.org/10.5194/essd-12-3269-2020.

Hodges, B.R., 2010. The importance of mixing and isolation time for desalination brine discharge. In: Proceeding of the International Engineering Conference on Hot Arid Regions, 6.

Ibrahim, H.D., Xue, P., Eltahir, E.A.B., 2020. Multiple salinity equilibria and resilience of Persian/Arabian Gulf basin salinity to brine discharge. Front. Mar. Sci. 7, 573. https://doi.org/10.3389/fmars.2020.00573.

IEA, 2017. Energy technology perspectives 2017 - analysis [WWW Document]. URL http s://www.iea.org/reports/energy-technology-perspectives-2017 (accessed 9.28.21).

Isik, O.R., 2013. Spin up problem and accelerating convergence to steady state. Appl. Math. Model. 37, 3242-3253. https://doi.org/10.1016/j.apm.2012.07.033.

Lykkebo Petersen, K., Heck, N., G. Reguero, B., Potts, D., Hovagimian, A., Paytan, A., 2019. Biological and physical effects of brine discharge from the carlsbad desalination plant and implications for future desalination plant constructions. Water 11, 208. https://doi.org/10.3390/w11020208.

MATLAB, 2017. 9.3.0.948333 (R2017b). The math works inc.

Metz, B., 2005. Intergovernmental panel on climate change. IPCC Special Report On Carbon Dioxide Capture and Storage. Cambridge University Press for the Intergovernmental Panel on Climate Change.

O’Dea, E.J., Arnold, A.K., Edwards, K.P., Furner, R., Hyder, P., Martin, M.J., Siddorn, J. R., Storkey, D., While, J., Holt, J.T., Liu, H., 2012. An operational ocean forecast system incorporating NEMO and SST data assimilation for the tidally driven European North-West shelf. J. Oper. Oceanogr. 5, 3-17. https://doi.org/10.1080/ 1755876X.2012.11020128.

Pachauri, R.K., Allen, M.R., Barros, V.R., Broome, J., Cramer, W., Christ, R., Church, J.A., Clarke, L., Dahe, Q., Dasgupta, P., 2014. Climate change 2014: synthesis report. Contribution of Working Groups I, II and III to the Fifth Assessment Report of the Intergovernmental Panel on Climate Change. IPCC.

Palomar, P., Losada, I.J., 2011. Impacts of brine discharge on the marine environment. modelling as a predictive tool, desalination, trends and technologies. IntechOpen. https://doi.org/10.5772/14880.

Queste, B.Y., Fernand, L., Jickells, T.D., Heywood, K.J., 2013. Spatial extent and historical context of North Sea oxygen depletion in August 2010. Biogeochemistry 113, 53-68. https://doi.org/10.1007/s10533-012-9729-9.

Raupach, M.R., Marland, G., Ciais, P., Le Quere, C., Canadell, J.G., Klepper, G., Field, C. B., 2007. Global and regional drivers of accelerating $\mathrm{CO}_{2}$ emissions. Proc. Natl. Acad. Sci. 104, 10288-10293. https://doi.org/10.1073/pnas.0700609104.

Remaili, T.M., Simpson, S.L., Bennett, W.W., King, J.J., Mosley, L.M., Welsh, D.T., Jolley, D.F., 2018. Assisted natural recovery of hypersaline sediments: salinity thresholds for the establishment of a community of bioturbating organisms. Environ. Sci.: Process. Impacts 20, 1244-1253. https://doi.org/10.1039/C8EM00092A.

Sánchez-Lizaso, J.L., Romero, J., Ruiz, J., Gacia, E., Buceta, J.L., Invers, O., Fernández Torquemada, Y., Mas, J., Ruiz-Mateo, A., Manzanera, M., 2008. Salinity tolerance of the mediterranean seagrass posidonia oceanica: recommendations to minimize the impact of brine discharges from desalination plants. Desalination 221, 602-607. https://doi.org/10.1016/j.desal.2007.01.119. European Desalination Society and Center for Research and Technology Hellas (CERTH)Sani Resort 22 -25 April 2007, Halkidiki, Greece.

Smyth, K., Elliott, M., 2016. Effects of changing salinity on the ecology of the marine environment. 10.1093/acprof:oso/9780198718826.003.0009.

Sumich, J.L., Morrissey, J.F., 2004. Introduction to the Biology of Marine Life. Jones \& Bartlett Learning.

Sumner, J., Bird, L., Smith, H., 2009. Carbon taxes: a review of experience and policy design considerations. Tech. Rep. 38.

Techtmann, S.M., Fortney, J.L., Ayers, K.A., Joyner, D.C., Linley, T.D., Pfiffner, S.M., Hazen, T.C., 2015. The unique chemistry of eastern mediterranean water masses selects for distinct microbial communities by depth. PLoS One 10. https://doi.org/ 10.1371/journal.pone.0120605. 
Topcu, H.D., Brockmann, U.H., 2015. Seasonal oxygen depletion in the North Sea, a review. Mar. Pollut. Bull. 99, 5-27. https://doi.org/10.1016/j. marpolbul.2015.06.021.

Wakelin, S.L., Artioli, Y., Holt, J.T., Butenschön, M., Blackford, J., 2020. Controls on near-bed oxygen concentration on the Northwest European continental shelf under a potential future climate scenario. Prog. Oceanogr. 187, 102400 https://doi.org/ 10.1016/j.pocean.2020.102400.

Zapantis, A., Townsend, A., Rassool, D., 2019. Policy priorities to incentivise large scale deployment of CCS [WWW Document]. Global CCS Institute. URL https://www. globalccsinstitute.com/resources/publications-reports-research

/policy-priorities-to-incentivise-large-scale-deployment-of-ccs/(accessed 10.27.21). 